\title{
A Study on Characteristics (Socio-Economic) Of Migrants In Chennai City
}

\author{
${ }^{1}$ K.Vinayakam, ${ }^{2}$ S.P.Sekar \\ ${ }^{1}$ Research Scholar, Department of Planning, SAP, Anna University, Chennai. \\ ${ }^{2}$ Professor, Department of Planning, SAP, Anna University, Chennai
}

\begin{abstract}
Chennai city is the forth largest metropolis. It has a population of 46.81 lakh by 2011 census; it is expected to grow more by 50.08 lakh. Considerable proportion of migrated population particularly in large and metropolitan cities lives in marginal settlements, slums and squatter areas with limited infrastructure services threatening health, environmental degradation of urban areas, traffic and other problems of urban areas. The study describes the factors contributing towards rural to urban migration. In rural areas, less employment opportunities, low wages, drought, lack of basic amenities, landlessness, social factors act as push factors and more employment opportunities, higher income, better wages, better facilities activities as pull factors towards the rural to urban migration
\end{abstract}

\section{Introduction}

In India the urban population rose from a small figure of 37.7 million in the year of 2011 (as per census) i.e. the 31.16 percent of the total population. The total population in the year of 2011 was 83.3 million in rural areas and 37.7 million in urban areas. . The India's total urban population is 37.7 million is very close to the American total population. The percent decadal growth of the population in rural and urban areas in the decade ending of the year 2011 was 12.2 and 31.8 percent in the urban population of the country during the preceding decade (as per census 2011).

Tamilnadu is one of the 28 states in India and $11^{\text {th }}$ largest state in India by area. It is the $2^{\text {nd }}$ largest state economy in India as of 2012. Tamilnadu is also the most urbanized area state in India. The total poplation is 7.21 million as per 2011 census in this the urban population is 3.49 million and rural population is 3.71 million. Tamilnadu population represents about $5.96 \%$ of the population of India. More people in Tamilnadu have moved from rural to urban areas in the last 10 years compared to other states, according to the 2011 census data. Tamilnadu tops the list of urbanized state with $48.45 \%$ of its population living in Urban areas.

Chennai city is the $4^{\text {th }}$ largest city in India and having $2^{\text {nd }}$ largest beach in the world. Chennai district is a district in the State of Tamilnadu out of 32 districts. It is the smallest of the entire district in the state, but has the highest human density. The most significant phenomenon in Chennai city is massive urbanization. Chennai city is the forth largest metropolis in India. It is the capital city of the Tamilnadu state and also having the major commercial, educational and industrial centers of south India. Chennai city Metropolitan Area covers 174 sq.kms. The population of Chennai city which was 14.16 lakh in 1951, increased 24.69 lakh in 1971, and further it was 38.41 lakh in 1991. Now in 2011 the population of the Chennai city was 46.81 as per the census of India.

The main objective of this paper is to study the various reasons of immigration for rural areas to urban area especially Chennai city.

\section{Methodology Of The Study}

This study this been carried out with the help of collection of the primary and secondary data. Chennai city having 10 corporation zones with 155 wards in 2011 , from this 10 corporation zones, it is difficult to find out the migrated people in all the areas, hence a random sampling of 305 was taken from the migrated people adopted in the areas and conduct interview to conduct socio-economic surveys to collect the information of the migrants. The field work was collected during April 2009 to April 2011.

The primary survey is mainly of the observations and interviews through the questionnaire methods. In this questionnaire that there are two major questions one is the overall quality of life with nine sub-questions and another one is overall impressions with five sub - questions, further the main conditions of the A. Education with five sub-questions, B. Housing and Basic Infrastructure with three sub-questions, C. Employment with three sub-questions, and D. Safety with three sub-questions. These questions were asked from 305 migrated peoples in the 10 zones of the Chennai City Corporation areas under random sampling method. 


\section{Overall Quality Of Life Of Migrated People}

The first question of the Overall Quality of Life is directions to evaluate your feelings relative to the quality of life and having the following questions:

1. Personal Life; 2. Wife/husband or 'significant'; 3. Co-workers; 4. The actual work you do; 5. The handling of problems in your life; 6. Ability to adjust to change in life; 7. Life and work as whole; 8. Overall contentment with the life and work; 9. The extent to which the life and work have been wanted it. From the above questions we had given options as follows:

1= Terrible; $2=$ Unhappy; $3=$ Mostly dissatisfied; $4=$ Mixed; $5=$ Mostly satisfied; $6=$ Pleased; $7=$ Delighted these options were filled according to the number of the options in each questions. These questions and options were asked 305 respondents and arrived the following the data from the questions. The number of persons responded for each questions and the options were given the following table.

TABLE - 1: THE QUALITY OF LIFE

\begin{tabular}{|c|c|c|c|c|c|c|c|c|}
\hline $\begin{array}{c}\text { QUALITY } \\
\text { OF LIFE } \\
\text { OF THE } \\
\text { RESPONDENT }\end{array}$ & $\begin{array}{c}1 . \\
\text { Terrible }\end{array}$ & $\begin{array}{c}2 . \\
\text { Un } \\
\text { happy }\end{array}$ & $\begin{array}{c}3 . \\
\text { Mostly } \\
\text { Dissatisfied }\end{array}$ & $\begin{array}{c}4 . \\
\text { Mixed }\end{array}$ & $\begin{array}{l}\quad 5 . \\
\text { Mostly } \\
\text { satisfied }\end{array}$ & $\begin{array}{c}6 . \\
\text { Pleased }\end{array}$ & $\begin{array}{c}7 . \\
\text { Delighted }\end{array}$ & $\begin{array}{l}\text { Total } \\
\text { Res- } \\
\text { pon- } \\
\text { dent }\end{array}$ \\
\hline Personal life & 4 & 9 & 15 & 81 & 77 & 81 & 38 & \multirow[t]{9}{*}{305} \\
\hline Wife/Husband & 4 & 10 & 20 & 68 & 85 & 79 & 39 & \\
\hline Co-worker & 5 & 7 & 19 & 81 & 94 & 77 & 22 & \\
\hline $\begin{array}{l}\text { Actual work } \\
\text { to do }\end{array}$ & 5 & 6 & 19 & 76 & 104 & 70 & 25 & \\
\hline $\begin{array}{l}\text { Handling of } \\
\text { problem in life }\end{array}$ & 6 & 9 & 10 & 103 & 111 & 56 & 10 & \\
\hline $\begin{array}{l}\text { Ability to } \\
\text { adjust the } \\
\text { change }\end{array}$ & 2 & 8 & 17 & 64 & 110 & 78 & 26 & \\
\hline $\begin{array}{l}\text { Life \& work } \\
\text { as a whole }\end{array}$ & 6 & 6 & 16 & 74 & 88 & 83 & 32 & \\
\hline $\begin{array}{c}\text { Overall } \\
\text { contentment } \\
\text { with life } \\
\text { \& work }\end{array}$ & 3 & 9 & 13 & 80 & 86 & 76 & 38 & \\
\hline $\begin{array}{l}\text { Extent of life } \\
\text { and work }\end{array}$ & 3 & 5 & 15 & 80 & 66 & 73 & 63 & \\
\hline
\end{tabular}

From the above most of the people are opted for with personal life is mixed and pleased, the Mixed, Mostly satisfied and pleased manner having the overall quality of life. with wife/husband is mostly satisfied, with the co-worker mostly satisfied, with the actual work to do is mostly satisfied, with handling of problem in life is mostly satisfied, the ability to adjust the change is mostly satisfied, the life \& work as a whole is mostly satisfied, the overall contentment with life \& work is mostly satisfied and the extent of life \& work is mixed. The average overall quality of life is mostly satisfied.

\section{Overall Impressions Of The Migrated People}

The second question is Overall impressions which direction to evaluate your feeling relative to the quality of life, using the scale of Better $=5$; Some $=3$; and Worse $=3$ with the following questions of 1 . Overall my physical well-being is; 2 .Overall my mental and emotional state is, ie. of Better $=5$; Some $=3$; and Worse $=3$ with the following questions of 1 . Overall my physical well-being is; 2 .Overall my mental and emotional state is; 3 . Overall my ability to handle stress is; 4.Overall my enjoyment of life and work is; 5 . Overall my quality of life is, these questions were asked to the individuation 305 respondents. The details are given in the table given below:

TABLE - 2: THE OVERALL IMPRESSIONS

\begin{tabular}{|c|c|c|c|c|}
\hline OVERALL IMPERSSIONS & 5. Better & 3. Some & 2. Worse & Total \\
\hline Physical well-being & 168 & 118 & 19 & 305 \\
\hline Mental \& Emotional & 147 & 130 & 28 \\
\hline Ability to handle stress & 155 & 122 & 27 \\
\hline Enjoyment of life and work & 157 & 121 & 27 \\
\hline Quality of life & 167 & 119 & 19 \\
\hline
\end{tabular}


From the above table it is clear that the physical well-being is better, mental and emotional is better, the ability to hand stress is better, the enjoyment of life and work is better and the quality of life is better, the over all impressions of the above is better.

The next questions which are given the conditions compared to 'before' your coming to Chennai are having the direction using the 1-7 scale of $7=$ Best; $6=$ Better; $5=\mathrm{Good} ; 4=$ Average; $3=\mathrm{Bad} ; 2=$ Worse; $1=$ Worst with that the Urban Environment with the questions of 1. Population density/congestion, 2. Accessibility to outside world, 3. Quality of environment, 4. Social spaces and cleanliness and 5. Overall look and fell. The details collected from the 305 respondents and given below:

\section{Educational Facility}

The Education Facility is important one in these five questions are taken place 1. Accessibility to education, 2. Affordability of education, 3. Quality of teacher, schools, and colleges, 4. Experience with educational services and 5. Distance, time and cost of getting there. The following table is shown the details about the Education Facility with 305 respondents.

\begin{tabular}{|c|c|c|c|c|c|c|c|c|}
\hline EDUCATION & $\begin{array}{c}7 . \\
\text { Best }\end{array}$ & $\begin{array}{c}\text { 6. } \\
\text { Better }\end{array}$ & $\begin{array}{c}\mathbf{5 .} \\
\text { Good }\end{array}$ & $\begin{array}{c}\text { 4. } \\
\text { Average }\end{array}$ & $\begin{array}{c}\text { 3. } \\
\text { Bad }\end{array}$ & $\begin{array}{c}\text { 2. } \\
\text { Worse }\end{array}$ & $\begin{array}{c}\text { 1. } \\
\text { Worst }\end{array}$ & Total \\
\hline $\begin{array}{c}\text { Accessibility to } \\
\text { education }\end{array}$ & 50 & 75 & 105 & 40 & 25 & 6 & 4 & 305 \\
\hline $\begin{array}{c}\text { Affordability of } \\
\text { education }\end{array}$ & 33 & 74 & 90 & 74 & 24 & 5 & 5 \\
\hline $\begin{array}{c}\text { Quality of } \\
\text { teacher, schools, } \\
\text { colleges }\end{array}$ & 44 & 66 & 88 & 64 & 37 & 5 & 1 & \\
\hline $\begin{array}{c}\text { Your experience } \\
\text { with educational } \\
\text { services }\end{array}$ & 25 & 69 & 101 & 73 & 26 & 9 & 2 \\
\hline $\begin{array}{c}\text { Distance, time } \\
\text { and cost of getting } \\
\text { there }\end{array}$ & 34 & 56 & 86 & 83 & 30 & 12 & 4 \\
\hline
\end{tabular}

From the above the Accessibility to educatrion is Good, the affordability of education is good, the Quality of teachers, schools, \& colleges is good, experiencewith educational services is good, Distance, time and cost of getting there is also good, from that the overall Education Facility is good.

\section{B. Housing And Basic Infrastructure Facility}

Next to Education the Housing and Basic Infrastructure Facility is important one in these three questions are taken place 1. Quality of housing \& infrastructure, 2. Maintenance of the house \& infrastructure, 3. Affordable, comfortable and livable. The following table is shown the details about the housing and basic infrastructure facility with 305 respondents.

\begin{tabular}{|c|c|c|c|c|c|c|c|c|}
\hline $\begin{array}{c}\text { HOUSING \& } \\
\text { BASIC INFRA- } \\
\text { STRUCTURE }\end{array}$ & $\begin{array}{c}\mathbf{7 .} \\
\text { Best }\end{array}$ & $\begin{array}{c}\mathbf{6 .} \\
\text { Better }\end{array}$ & $\begin{array}{c}\mathbf{5 .} \\
\text { Good }\end{array}$ & $\begin{array}{c}\text { 4. } \\
\text { Average }\end{array}$ & $\begin{array}{c}\text { 3. } \\
\text { Bad }\end{array}$ & $\begin{array}{c}\text { 2. } \\
\text { Worse }\end{array}$ & $\begin{array}{c}\text { 1. } \\
\text { Worst }\end{array}$ & Total \\
\cline { 1 - 6 } $\begin{array}{c}\text { Quality of your } \\
\text { housing \& } \\
\text { infrastructure }\end{array}$ & 26 & 62 & 101 & 73 & 26 & 13 & 4 & 305 \\
\hline $\begin{array}{c}\text { Maintenance } \\
\text { of the } \\
\text { house \& } \\
\text { infrastructures }\end{array}$ & 20 & 58 & 93 & 85 & 36 & 8 & 5 & \\
\hline $\begin{array}{c}\text { Affordable, } \\
\text { comfortable } \\
\text { \& liveable }\end{array}$ & 22 & 61 & 85 & 82 & 38 & 15 & 2 & \\
\hline
\end{tabular}

From the above the Quality of housing \& infrastructure is good, the Maintenance of the house \& infrastructure is good and Affordable, comfortable and livable is also good, from that the overall Housing and Basic Infrastructure Facility is good.

\section{EMPLOYMENT OPPORTUNITY}

Next to Housing and Basic Infrastructure facility the Employment Opportunity is important one in these three questions are take place 1. Supports family/household comfortably, 2. Challenging and likeable, 3. 
No hazards and sufferings. The following table is shown the details about the employment opportunity with 305 respondents.

\begin{tabular}{|c|c|c|c|c|c|c|c|c|}
\hline EMPLOYMENT & $\begin{array}{c}7 . \\
\text { Best }\end{array}$ & $\begin{array}{c}\mathbf{6 .} \\
\text { Better }\end{array}$ & $\begin{array}{c}\mathbf{5 .} \\
\text { Good }\end{array}$ & $\begin{array}{c}\mathbf{4 .} \\
\text { Average }\end{array}$ & $\begin{array}{c}\text { 3. } \\
\text { Bad }\end{array}$ & $\begin{array}{c}\text { 2. } \\
\text { Worse }\end{array}$ & $\begin{array}{c}\text { 1. } \\
\text { Worst }\end{array}$ & Total \\
\hline $\begin{array}{c}\text { Supports family/ } \\
\text { household } \\
\text { comfortably }\end{array}$ & 32 & 62 & 118 & 59 & 28 & 6 & 0 & 305 \\
\hline $\begin{array}{c}\text { Challenging } \\
\text { \& likeable }\end{array}$ & 28 & 73 & 112 & 65 & 19 & 8 & 0 \\
\hline $\begin{array}{c}\text { No hazards } \\
\text { \& sufferings }\end{array}$ & 30 & 68 & 85 & 75 & 38 & 8 & 1 \\
\hline
\end{tabular}

From the above the Supports family/household comfortably is good, the Challenging and likeable is good, the No hazards and sufferings is also good, from that the overall Employment Opportunity is good.

\section{SAFETY OF THE LIFE}

Next to Employment, Safety of the Life is Very important one in these three questions are taken place 1. Individual Safety, 2. Women's and Children's Safety, 3. Community Safety. The following table is shown the details about the Safety of the Life with 305 respondents.

\begin{tabular}{|c|c|c|c|c|c|c|c|c|}
\hline SAFETY & $\begin{array}{c}7 . \\
\text { Best }\end{array}$ & $\begin{array}{c}\mathbf{6 .} \\
\text { Better }\end{array}$ & $\begin{array}{c}\mathbf{5 .} \\
\text { Good }\end{array}$ & $\begin{array}{c}\mathbf{4 .} \\
\text { Average }\end{array}$ & $\begin{array}{c}\text { 3. } \\
\text { Bad }\end{array}$ & $\begin{array}{c}\text { 2. } \\
\text { Worse }\end{array}$ & $\begin{array}{c}\text { 1 } \\
\text {.Worst }\end{array}$ & Total \\
\hline $\begin{array}{c}\text { Individual } \\
\text { safety }\end{array}$ & 22 & 46 & 114 & 64 & 41 & 14 & 4 & 305 \\
\hline $\begin{array}{c}\text { Women's \& } \\
\text { children's } \\
\text { safety }\end{array}$ & 12 & 49 & 96 & 78 & 46 & 18 & 6 \\
\hline $\begin{array}{c}\text { Communiy } \\
\text { safety }\end{array}$ & 17 & 49 & 112 & 84 & 21 & 17 & 5 \\
\hline
\end{tabular}

From the above the individual safety is good, the women's and children's safety is good and the community safety is also good, from that the overall health facility is good.

The details are taken from the Chennai City Corporation zones of ten numbers with random sampling method. From the above details of the Overall Quality of Life of the Migrated People, the Overall impressions of the Migrated People, the present main status of the Educational Facility, Housing and Basic Infrastructure Facility, Employment Opportunity and the Safety of the Life has been analyzed with 305 respondents of the migrated people. Out of that all the above facilities which are given in good manner. Even though the government and the government organizations are try to give the above facility in a best manner then only they are satisfied in the migrating area. Other then the Best, Better and Good in some respondents given as Average, $\mathrm{Bad}$, Worse and Worst manner for them also the government and the government organizations are try to give the above facility in good manner then only the migrated people satisfied to live in good condition

\section{Conclusion}

The details are taken from the Chennai City Corporation zones of ten numbers with random sampling method. From the above details of the Overall Quality of Life of the Migrated People, the Overall impressions of the Migrated People, the present status of the Educational Facility, Housing and Basic Infrastructure Facility, Employment Opportunity and the Safety of the Life has been analyzed with 305 respondents of the migrated people. Out of that all the above facilities which are given in good manner. Even though the government and the government organizations are try to give the above facility in a best manner then only they are satisfied in the migrating area. Other then the Best, Better and Good in some respondents given as Average, Bad, Worse and Worst manner for them also the government and the government organizations are try to give the above facility in good manner then only the migrated people satisfied to live in good conditions.

\section{References:}

[1] Migration in India, hHp://www.india no officer.com/for uns/current-issues/5981-migration- i..18/7/2009

[2] Mahendra K.Premi, 1987'Pattterns and process of migration", Allied Publishers Pvt.Ltd.: 1987,Pg.No.258-259 \& Pg.283.

[3] K.Nagaraj, 1987 "Urbanization in Tamilnadu,Karnataka \& Andhra Pradesh, A Comparative prime for 1961-1981 Pg.No.348.

[4] Censes of India 2011.

[5] Migration websites.

[6] Data Collections. 